\title{
THE CHALLENGE OF HUMAN RIGHTS EFFECTIVENESS IN THE CONTEXT OF ECONOMIC GLOBALIZATION: WHAT IS THE WORK OF THE UNITED NATIONS?
}

\section{O DESAFIO DA EFICÁCIA DOS DIREITOS HUMANOS NO CONTEXTO DA GLOBALIZAÇÃO ECONÔMICA: QUAL É O TRABALHO DAS NAÇÕES UNIDAS?}

\section{PATRICIA AYUB DA COSTA}

Doutoranda em Direito Internacional pela Universidade de São Paulo. Mestre em Direito Negocial pela Universidade Estadual de Londrina. Professora de Direito Internacional na Universidade Estadual de Londrina. Advogada.

\begin{abstract}
In this paper, one analyzes the restructuring of power in the context of economic globalization and the recognition of the individual as a subject of international law. It recognizes that the strengthening of human rights impacts on state sovereignty, and its effectiveness finds obstacles in face of international trade transnationality and the lack of international accountability for companies' violations of human rights. It identifies the importance of strengthening international human-rights law, international solidarity, cooperation of States and the implementation effective actions. It analyses the work of the United Nations, especially in approving John Ruggie's "Protect, Respect, Remedy" Framework and his Guiding Principles for Business and Human Rights. It concludes that there has been progress, athough it is necessary to go further in order to implement and give effect to the principles.
\end{abstract}

KEYWORDS: Human Rights; Transnational Companies; States; Globalization; United Nations. 


\section{RESUMO}

Neste artigo, analisa-se a reestruturação do poder no contexto da globalização econômica e o reconhecimento do indivíduo como sujeito do direito internacional. Reconhece que o fortalecimento dos impactos dos direitos humanos na soberania do Estado e sua eficácia encontram obstáculos em face da transnacionalidade do comércio internacional e da falta de responsabilidade internacional pelas violações de direitos humanos por parte das empresas. Identifica a importância de fortalecer o direito internacional dos direitos humanos, a solidariedade internacional, a cooperação dos Estados e a implementação de ações efetivas. Analisa o trabalho das Nações Unidas, especialmente ao aprovar o Marco de Proteção, Respeito e Remédio de John Ruggie e seus Princípios Orientadores para Empresas e Direitos Humanos. Conclui que houve progresso, embora seja necessário ir mais longe para implementar e dar efeito aos princípios.

PALAVRAS-CHAVE: Direitos humanos; Empresas Transnacionais; Estados; Globalização; Nações Unidas.

\section{INTRODUCTION}

Profound changes have taken place in the international economic, social, legal and commercial landscapes since the post-World War period, such as the intensification of globalization, the creation of multilateral and regional organizations, and the technological advancements both in transportation and communication, which have strengthened international trade relations by breaking borders for the movement of goods, services, investments and people.

Said transformations affected state sovereignty, whether by means of a state's relationship with international organizations, transnational corporations and even with their citizens, as a result of the protection of human rights. In view thereof, one cannot study International Law, public and private relations, or the relations among their respective actors still focusing simply the State; instead, the focus should be on humanity. It is necessary to re-analyse the State in the scope of 
international relations and sovereignty with a critical eye, taking into account political, social, economic, cultural and legal issues that concern every international society, especially the individual person.

The liability for human rights violations, either within or beyond the geographical borders of transnational corporations, is one of the challenges imposed to international law in this century, and it requires an steady performance by all international actors, beginning with the United Nations.

\section{THE RESTRUCTURING OF POWER WITHIN THE CONTEXT OF ECONOMIC GLOBALIZATION}

The phenomenon of globalization is everything by new, and it is characterized by an intensification in human, economic, social, cultural, commercial and legal relations. Breaking of geographical borders has both positive and negative impacts within the structures of a state, and leads to reflection on the reformulation of power structures, including sovereignty itself.

\footnotetext{
Globalization of the consecrated economy through the breaking of classical geographical boundaries, weakening of the government machinery, the process of bloc-oriented regional integration, flexibilization of labor relations, rise of large economic groups with - actually greater than some States' powers, the creation of quasi-governmental international entities, as well as the extraordinary evolution of telecommunications, were all facts that occupied the twentieth century and which required one to rethink of the concept of sovereignty (NUNES JUNIOR, 2003, p. 162).
}

Within such context of globalization, the interrelationship held amongst international actors is changed as well. Transnational companies gain importance in States' decision-making with regards to internal and external policies, including those concerning human rights.

In the face of a contemporary vision, international relations - especially those of investment - must become expressions of human dignity, fostering a sustainable development which is not always reflected in their practice. 
This is even more so considering that corporate investors are often, under investment agreements, not explicitly obliged to observe fundamental human rights even though they exert considerable power over individuals, communities and indigenous populations. Such assertions have strengthened the normative link between human rights Law and international Law on foreign investment on a general level. (CERNIC, 2010, p. 245).

There is no way to dissociate the importance of protecting human rights against the strengthening of both transnational investors and companies. In this sense:

\footnotetext{
The link between human rights and international trade would lie in an increasingly perceptible link between comparative trade advantages and the discrepancies found in labor regimes across countries, many of which stem from violations of the rights granted by international treaties and conventions. Long working hours, low wages, using of child labor and inadequate working conditions would be forms of "social dumping, leading to an increase in exports as a result of lower production costs. (AMARAL JÚNIOR, 1999, p. 202).
}

Since human rights change right premises and duties within the international arena, leading towards the recognition of the individual as a subject of international law, there is an impact on international relations. The State continues to be an essential subject for international relations, but its action must be taken in the interests of human beings. Thus, sovereignty becomes more flexible and no longer impenetrable, and this change in the structure of power also changes the very function of contemporary international law (JUBILUT, 2012, p. 200), which shall evolve to humanization in the perspective of Cançado Trindade.

Humans are social beings capable of relationships in the most diverse forms: personal, social, political and commercial. In additional to several other skills, said capacity enabled the accumulation of riches and one's exchange with others in order to obtain whatever else one needed and was unable to produce, making that primitive commerce evolve to today's virtual and global commerce. Paradoxically, it became a form of social interaction able to bring such different cultures together for the sake of profit that no longer observes or is retained by borders. Being real, virtual, domestic or transnational, it is a great innovator of legislation, such as Community law and many types of formal agreement instruments. 
Nevertheless, such global trade is not totally free and fair. Antonio Carlos Rodrigues do Amaral (2004, p. 53) ponders that, despite of imposing risks and challenges, globalization of markets also brings many opportunities for expanding the benefits of free trade, provided that more equitable conditions for trade are established by extinguishing unjustifiable barriers to products and services from developing countries.

International trade may be viewed as an agent that enables peace and human development, considering that one's dependence on others, the approximation of different peoples and exchange of their knowledge and customs should be used for cooperation; however, very little has been done by the international actors in this regard. Following that reasoning, Roberto Di Sena Junior (2006, p. 49) reaffirms that, from a theoretical point of view, international trade aims to promote peoples' well-being by increasing the real income provided by the expansion of trade flows.

As mankind has not yet been able to live such experience, and commercial relations generate a series of conflicts from the most varied instances, International Law is left with the responsibility to harmonize such relations. It is then necessary to create a new international-law framework that will govern over a globalized society "in which the processes of normative design take place at the level of decentralized social and economic interdependencies" (MARQUES NETO, 2002, p. 111-112). It is also possible to verify that the expansion is not only of a public, but also of mercantile nature.

As observed by Alberto do Amaral Júnior (2008, p. 36-37):

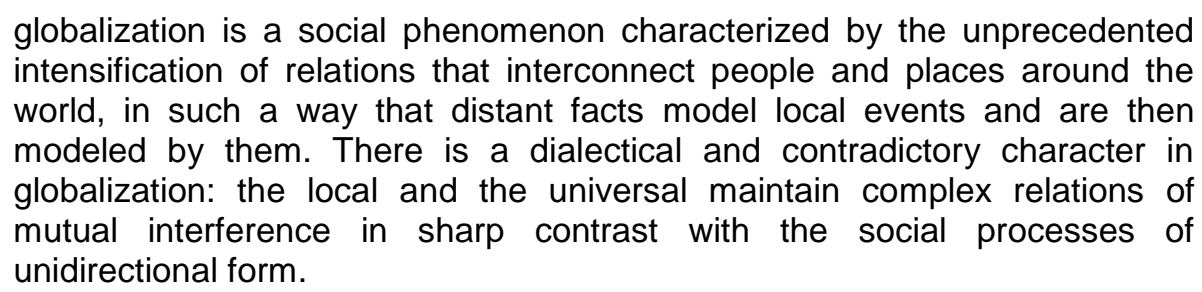

Transnational companies appear in this scenario as protagonists with economic power. They often negotiate with States on an equal basis, and not rarely incur in violations of human rights in pursuit of their inherent profit. 
Companies would be agents of technological globalization to confront the State, especially transnational corporations that succeed in causing instability and volatility in financial markets (making or unmaking "strategic" investments), so that one of Government's main jurisdictions, namely regulation of the economy and market, ends up limited by the effective power that these economic agents present. (FORTES; POMPEU, 2017, p. 69-70)

As States need to attract investors to promote human development, and expand markets to promote economic and social well-being, they subject themselves to the pressure by transnational corporations and financial operators to make tax and labor laws more flexible. "Daily agreements between States and transnational corporations obscure the distinction between public and private interests." (AMARAL JÚNIOR, 2008, p. 41). It demonstrates that the balance between interests is everything but simple. The challenge imposed to international society is to achieve sustainable development for all its actors.

Antônio Augusto Cançado Trindade (2007, p. 222) warns of the evil caused by the globalization of economies that privilege the opening of borders for capital, investment, goods and services, but not necessarily for people, resulting in "the statistically proven - tragic increase of marginalized and excluded people all over the world in an updated manifestation of evil social neo-Darwinism. "

José Eduardo Faria (1999, p. 63) identifies that "sovereignty compulsorily shared" with international corporations has forced the State to revise its legislative policy, reformulate the structure of its positive law, and reshape jurisdiction by means of deregulation, de-legitimation and de-institutionalization strategies implemented in parallel promotion of public monopolies the breakdown.

At the same time that State action is rejected in the first stage of protecting human rights (individual rights), it is necessary to regulate economic and social rights, which reveals the paradigm of globalization and human rights.

This is because the human rights paradigm, as shaped by the post-World War II developments, comes to rely on the responsibility of State actors, making them the only direct holders of obligations. But economic aspects of globalization such as the rise of international trade and financial flows across borders, deregulation and privatization and the reduction of the role of the state, erode the capacity of States to take active measures required to respect, protect and fulfill human rights in their territorial jurisdiction. So something that - from a traditional civil and political rights perspective - used 


\begin{abstract}
to be welcomed (the receding role of the State vis-à-vis the sphere of individual freedoms) - from an ESCRs perspective - represents a handicap. Economic and social rights call, by their essence, for a State more capable of taking active measures in economic and social policy-even when these active measures do not amount to intervention but to a more active regulation and oversight of private sector activity. (CALIARI, 2009, p. 142).
\end{abstract}

One observes that the market logic has been unable to satisfy mankind's common interests. "The human being is an end in itself, and it is not reduced to a mere 'consumption resource' or 'production agent'. In short, today more than never before, one needs consciousness and cultivation of the true values." (CANÇADO TRINDADE, 2007, p. 280)

In this sense, one shall analyse how human rights are at the same time the cause of a new international structure, insofar as they interfere in State sovereignty and must guide public policies in search of investments and regulation of international trade, and at the same time, they are victims of States and transnational corporations.

\title{
3 HUMAN RIGHTS AS THE CAUSE AND VICTIM OF INTERNATIONAL RESTRUCTURING
}

The concern over human rights after World War II brought great repercussion to international law, moving it from a purely state relevance sphere to the recognition of the international subjectivity of human beings, demanding greater cooperation and new values (JUBILUT, 2012 , p.184-185)

Thus, the Universal Declaration of Human Rights of 10th December 1948 appears as a framework for the reconstruction of human rights, characterized by universality and indivisibility. This moment marks the strengthening of the idea that human rights cannot be restricted to the internal jurisdiction of States, generally the violators thereof.

According to Flavia Piovesan (2000, p. 19), this new conception has two consequences: the first being the revision of the traditional notion of absolute 
sovereignty of the State; the second, individuals having their rights protected within the international arena for their condition as a subjects of right.

Antônio Augusto Cançado Trindade (2006, p. 400) highlights the evolution of international law in the second half of the last century, fostered by the work of the United Nations, specialized agencies and other regional organizations. $\mathrm{He}$ contextualizes that the rise of former-colony new States generated an urgency for effective self-determination of peoples, which demanded the United Nations' attention economic and social domains, in addition to international trade, without leaving its continuous preoccupation with peace and war. All those changes in international society have contributed to a new understanding of international law and its subjects.

Liliana Lyra Jubilut (2012, p. 204-206) argues that the axiological rescue, with the consecration of human beings as subjects of international law, allows an international constitutionalism with values such as international security and protection of human rights as a central point, which does not necessarily stem from institutions or norms, rather from the "replacement of human beings as the center of power and law, no longer as mere instruments thereof" (JUBILUT, 2012, p. 206).

In this line, Canotilho (apud FORTES; POMPEU, 2017, p. 68) speaks of global constitutionalism governed by human rights and international organizations in order to stabilize an international legal-political system characterized by (i) a more horizontal relationship between state governments, (ii) an emergence of coercivity, and (iii) the constitutional centrality of protection of human dignity.

Raphael Carvalho de Vasconcelos (2016, p. 273) emphasizes that protection of the human being translates into principles inserted in the texts of treaties and constitutions, carrying a strong pretension of universality and international morality, whose concept is open, mutant, incomplete and varies according to the different local modalities.

However, Cançado Trindade (2007, p. 225) shows a major concern with the erosion of States' ability to protect human beings' economic, social and cultural rights under their respective jurisdictions against economic globalization. "Beyond the State and market, we must seek the pre-eminence of the highest values, those capable of guiding actions and meeting human aspirations. The State exists for those 
human beings composing it, and not vice versa. "(CANÇADO TRINDADE, 2007, p. 279)

In this way, human rights must be instances of States's change in order to leave dependency, move towards a necessary cooperation, and outline a perspective of solidarity for the development of mankind as as a whole.

According to Vladimir Oliveira da Silveira and Samyra Haydêe Dal Farra Naspolini Sanches (2015, p. 147), solidarity is part of human rights role, and does not only relativize States' sovereignty; instead, it also commits beyond government, the private individual, corporations and the community to fulfill the common aspirations of all humanity.

States are incumbent of the important function of regulating national and international relations, and must avoid abuses such as protectionism or speculation by private agents that may damage the economy and social relations. Based upon the principle of international solidarity, they should seek an opportunity to find common solutions for the reconstruction of solid economic, juridical and social pillars.

Inherent to effective citizenship, material equality presupposes civil liberty, political participation and satisfaction of social needs, and the State may be both the guarantor of human rights as well as their violator. That is why it is necessary to strengthen legal systems with participatory democratic procedures. In this sense, economic development dissociated from social aspects provides perverse inequalities for democracy, and serves as a support for violations of economic and social human rights.

The words of Alberto do Amaral Júnior (2008, p. 475) remind that "there is an inseparable link between human rights, democracy and peace", and therefore "the protection of human rights in the international arena can be a valuable instrument for building democracy in a cosmopolitan dimension."

Aldo Caliari (2009, p. 146-150) numbers several strategies that may be employed concomitantly and/or jointly to promote the accountability of economic activities in face of human rights: a) Awareness-building amongst grassroots, other NGOs, government officials and broader public; b) Capacity-building and public mobilization; c) Influencing decisions, policy- and rule-making by national governments; d) Influencing decisions, policy- and rule-making in international fora 
and institutions; e) Norm-development at the national level; f) Norm-development at international level; g) Jurisprudence by judicial and quasi-judicial mechanisms at the national level; h) Jurisprudence by judicial and quasi-judicial mechanisms, as well as human rights supervisory and monitoring bodies at international level; i) Project-level Human Rights impact assessment; j) Improving access to information.

It is therefore essential to ascertain the role of international law in helping balance international economic relations and guarantee human rights.

\section{THE ROLE OF INTERNATIONAL LAW IN THE BALANCE OF INTERNATIONAL RELATIONS: THE WORK OF THE UNITED NATIONS}

Celso Lafer (apud SABA, 2002, p. 59) clarifies that Public International Law (PIL) follows the momentum of global transformation, since its focus changed from States and their sovereignty to the interests of Humanity. "In other words, PIL did not cease to base itself on States' sovereignty; yet, it started to consider it in a relation of reciprocal limitation to the principle of international solidarity."

Thus, the exercise of law through power of the State and international organizations is fundamental to inhibit the lucrative interests of some from being the reason for international relations to the detriment of sustainable development and social justice of the majority. At this historical moment, in case there is no global cooperation between all international actors due to the degree of interdependence existing, there may be discredit in economic, social and legal institutions, especially in public international law and integration.

Since its establishment, the United Nations has already provided for the right to development and the need for international economic and social cooperation, as provided for in Articles $55^{1}$ and $56^{2}$ of the Charter of the UN.

\footnotetext{
${ }^{1}$ Article 55: With a view to the creation of conditions of stability and well-being which are necessary for peaceful and friendly relations among nations based on respect for the principle of equal rights and self-determination of peoples, the United Nations shall promote: a. higher standards of living, full employment, and conditions of economic and social progress and development; b. solutions of international economic, social, health, and related problems; and international cultural and educational cooperation; and c. universal respect for, and observance of, human rights and fundamental freedoms for all without distinction as to race, sex, language, or religion.
} 
The First United Nations Development Program (1961-1970) was essential to understand that underdevelopment has an impact on international society as a whole; therefore, it needs to be solved through international solidarity. So the very understanding of the term "development" changes over time to migrate from a strictly economic context to an integrated approach between the economic and the social aspects, until it is recognized as human rights by the UN General Assembly under Resolution 41/128 ${ }^{3}$, dated 4th December 1986. (PERRONE-MOISÉS, 1999, p. 180187)

Cláudia Perrone-Moisés (1999, p. 191) explains that, in its international dimension, the right to development has three premises, namely: a) the development of any country depends on the international plan; b) the increasing recognition of societies' interdependence leads to the need for a global approximation of problems related to development; and (c) global development faces transnational economic problems that are expressed through models of domination and dependence, disadvantageous trade relations, and the concentration of power by privately-held transnational economic operators.

These premises show not only that the State and international organizations are responsible for development, but also other actors such as NGOs, privately-held companies, trade unions and many other groups that interfere in economic and social relations (PERRONE -MOISÉS, 1999, p. 194). The entire international society is accountable for the implementation of human rights, in particular for the achievement of Articles XXII ${ }^{4}$ and XXVIII ${ }^{5}$ of the Universal Declaration of Human Rights 1948.

\footnotetext{
${ }^{2}$ Article 56: All Members pledge themselves to take joint and separate action in co-operation with the Organization for the achievement of the purposes set forth in Article 55.

${ }^{3}$ Article 1. 1. The right to development is an inalienable human right by virtue of which every human person and all peoples are entitled to participate in, contribute to, and enjoy economic, social, cultural and political development, in which all human rights and fundamental freedoms can be fully realized. 2. The human right to development also implies the full realization of the right of peoples to selfdetermination, which includes, subject to the relevant provisions of both International Covenants on Human Rights, the exercise of their inalienable right to full sovereignty over all their natural wealth and resources.

${ }^{4}$ Article 22. Everyone, as a member of society, has the right to social security and is entitled to realization, through national effort and international co-operation and in accordance with the organization and resources of each State, of the economic, social and cultural rights indispensable for his dignity and the free development of his personality.

${ }^{5}$ Article 28. Everyone is entitled to a social and international order in which the rights and freedoms set forth in this Declaration can be fully realized.
} 
As pointed by Alberto do Amaral Júnior (1999, p. 201), "the obligation to observe human rights pertains not only to individuals, but also to the State."

It is well known that the United Nations serve as a forum for the discussion and implementation of human rights, either by means of soft law or international treaties. Concerned about this scenario in which companies abuse human rights, the United Nations has invested heavily in an in-depth research that has collected data from businesses, governments, civil society, affected individuals and communities, lawyers, investors and other interested parties.

This initiative began with the attempt to draft a binding text to protect human rights in the face of international corporations, though such project was not approved by the Human Rights Council.

However, by means of Resolution 17/4 of 16 June 2011, the UN Human Rights Council endorsed the Guiding Principles on Business and Human Rights presented by Professor John Ruggie, Special Representative of the SecretaryGeneral of the United Nations. Those principles provide a global parameter on what is expected from States and companies in relation to the very companies and human rights.

The Guiding Principles were developed to implement the "Protect, Respect and Remedy" Framework that John Ruggie presented to the United Nations in 2008. John Ruggie (2013, p. 13) explains that the Framework is based on three pillars:

1. The state duty to protect against human rights abuses by third parties, including business enterprises, through appropriate policies, regulation, and adjudication; 2 . An independent corporate responsability to respect human rights, which means that business enterprises should act with due diligence to avoid infringing on the rights of others and address adverse impacts with which they are involved; 3 . The need for greater access by victims to effective remedy, both judicial and nonjudicial. Simply put: states must protect; companies must respect; and those Who are harmed must have redress.

Patricia Feeney $(2009$, p.168) explains that the "Protect, Respect and Remedy" Framework has been well received by the international society. "This broad framework was welcomed by business associations, governments and many civilsociety groups, who appreciated the fact that it encapsulated many of the 
conclusions that expert bodies and human-rights advocates had previously expressed."

However, the Ruggie report is not exempted of criticism, such as David Bilchitz's (2010, p. 207), who advocates that companies only had negative obligations (to respect), and there was a lack in the imposition of positive actions for the implementation of human rights.

\begin{abstract}
However, even with this deeper analysis of what Ruggie's framework envisages for corporate obligations, it is still evident that his framework narrows the focus of corporate obligations to the largely 'negative' task of avoiding harm to fundamental rights - whether it is the corporation's own actions or those it is associated with - rather than requiring that corporations assume positive obligations actively to take steps to assist in the realisation of human rights.
\end{abstract}

In his work entitled "Just Business", Ruggie (2013, p. 13-14) shares his experience in designing the Guiding Principles, their challenges, employed strategies and the respective following steps. There were difficulties indeed, since it needed to include different actors with distinct goals without confronting their comfort zones. While corporations wanted rules without binding effects, activists demanded binding rules. States were in conflict: even when they acknowledged the necessity to act, they found themselves under the pressure of corporations.

Faced with the 1990s worldwide economic transformations with trade liberalization, internal deregulation and privatizations, Ruggie summarizes that:

\begin{abstract}
In relation to business and human rights, two features stood out on this transformed economic landscape: it became clear that many governments were unable or unwilling to enforce their domestic laws in relation to business and human rights, where such laws existed at all; and multinational firms were unprepared for the need to manage the risks of their causing or contributing to human rights harm through their own activities and business relationships. Advocacy groups organized campaigns against multinationals. Local communities began to push back, particulary against extractive companies with their large physical and social footprints. The language of human rights became part of the vernacular of affected individuals and groups around the world, emerging as an increasingly prevalent narrative challenging harmful corporate practices. (RUGGIE, 2013, p. 16-17).
\end{abstract}

There is a total of 31 principles intended to provide a normative platform to provide guidance on the legal and political measures that States, in their fulfillment of 
respective human-rights obligations, can put into practice to ensure that companies will respect human rights. John Ruggie (2013) stated that those principles mark the end of a beginning, and provide a solid and practical foundation upon which learning and good experiences can be constructed.

The first guiding principle (GP1) provides that "States must protect against human rights abuse within their territory and/or jurisdiction by third parties, including business enterprises. This requires taking appropriate steps to prevent, investigate, punish and redress such abuse through effective policies, legislation, regulations and adjudication".

Guiding Principle 3 establishes normative functions over the State, which must also guide companies. When the State has a stake in companies, it must ensure and monitor that there is no violation of human rights (GP 4) and demand respect for human rights in its commercial transactions (GP 5 and GP6). GP9 requires investment agreements to be achieved by obligations to respect human rights. GP10 encourages States to disseminate informative principles in the multilateral organizations they participate in. Guiding principles 11 to 24 govern the responsibilities of companies to respect human rights.

Guiding Principle 11 provides that "Business enterprises should respect human rights. This means that they should avoid infringing on the human rights of others and should address adverse human rights impacts with which they are involved". Human rights "understood, at a minimum, as those expressed in the International Bill of Human Rights and the principles concerning fundamental rights set out in the International Labour Organization's Declaration on Fundamental Principles and Rights at Work". (GP12)

Companies must avoid and prevent the negative impacts of their actions and those of third parties with whom they interact (GP13), regardless of their size, sector, operational context, owner and structure (GP14).

Guiding Principle 15 outlines what companies must do to observe human rights, while principles 16 to 24 set operational standards, such as political commitments, human rights audits, monitoring of the measures to prevent adverse impacts on human rights, etc. 
15. In order to meet their responsibility to respect human rights, business enterprises should have in place policies and processes appropriate to their size and circumstances, including: 16 (a) A policy commitment to meet their responsibility to respect human rights; (b) A human rights due diligence process to identify, prevent, mitigate and account for how they address their impacts on human rights; (c) Processes to enable the remediation of any adverse human rights impacts they cause or to which they contribute.

Still geared towards companies, GP22 in its turn determines that the adverse impact must be remedied whenever it is identified: "Where business enterprises identify that they have caused or contributed to adverse impacts, they should provide for or cooperate in their remediation through legitimate processes."

The GP25 opens the chapter on Access to Repair Mechanisms, as a fundamental principle:

25. As part of their duty to protect against business-related human rights abuse, States must take appropriate steps to ensure, through judicial, administrative, legislative or other appropriate means, that when such abuses occur within their territory and/or jurisdiction those affected have access to effective remedy.

The GP 26 provides that States must provide adequate judicial remedies while GP27 and GP28 provide extrajudicial remedies for complaints on the violation of human rights. GP30 also encourages corporations to provide mechanisms by which such complaints can be made.

Guiding Principle 31 finally states that, in order to ensure its effectiveness, non-judicial grievance mechanisms, both State-based and non-State-based, should be: a) Legitimate; b) Accessible; c) Predictable; d) Equitable; e) Transparent; f) Rights-compatible; g) A source of continuous learning; and operational-level mechanisms should also be: (h) Based on engagement and dialogue.

When asked about the impact of the Guiding Principles in an interview with Conectas, Sheldon Leader (2012, p. 108) responded that:

They are a step forward. It is, I do believe, something like what John Ruggie, formerly the United Nations Secretary-General's Special Representative for Business and Human Rights, calls a "constitutional moment". We have very general statements that are nevertheless clear enough to render certain kinds of arguments no longer viable. For example, the argument that "my suppliers are simply arms-length contractors, and I have no further obligations to check them out and deal with them" can no longer be held if 


\begin{abstract}
these principles are even minimally accepted. The requirement in the Guiding Principles that there be this vertical responsibility-that parent companies take more responsibility for their role-is a clear statement that goes beyond the increases in types of parent company responsibility that we are seeing in some courts. So the Guiding Principles are saying something quite definite, but nevertheless very general. And that is the dangerous part: there are going to be attempts to fill in the blanks in a way that is not really going to satisfy human rights requirements. So I think the Guiding Principles are a sign of progress, but they also open up a new terrain for potential regression.
\end{abstract}

A Working Group on Business and Human Rights was established in order to continue John Ruggie's work materialize his Guiding Principles. This group has developed an interpretation guide to the Guiding Principles, and chapter I thereof defines the key concepts to be used. On the other hand, chapters II and III focus on the essence of the Guiding Principles that address corporate responsibility to respect human rights, with questions and answers that help interpreting each principle and the implications of their implementation.

In chapter five of "Just Business", Ruggie (2013) thinks beyond the guiding principles and challenges the drafting of a binding international legal instrument on the relationship of States, companies and human rights.

One must acknowledge that dialogue has started, but there is still a lot to be done in order to put the guiding principles into practice - even to reach a human rights treaty that would enforce the responsibility of transnational corporations for their violations of human rights. It is clear that such stage of humanity will demand a greater commitment by States and organized society itself.

\title{
CONCLUSION
}

Despite the aforementioned progresses, in the sense if having an environment for the discussion of human rights and their relation with companies and States, one witnesses a moment of increasing nationalism, xenophobia, and economic and humanitarian crisis.

The greatest difficulty for human rights is their implementation, which requires constant watch to avoid regression. One has verified UN's importance in 
fomenting the debate and bringing all interested parties together for the discussion and design not only of the "Protect, Respect and Remedy" Framework, but alson the Guiding Principles. Despite being soft law, their importance in the defence of human rights has been acknowledged by States, companies and non-governmental organizations. Creator John Ruggie identified them as the end of the beginning. Once the first step was taken, now its implementation is necessary.

As asserted by Antonio Augusto Cançado Trindade

\begin{abstract}
I now clearly understand that working for the protection of human rights is like the Myth of Sisyphus; that is, a neverending task. It is like being constantly pushing a rock up the mountain, which then falls back only to be carried up again. In between advances and setbacks, one develops a work of protection. When walking down the mountain so to push the roch up, one becomes aware of his human condition its accompanying tragedy. However, one shall keep his fight. In fact, there is no other choice. (CANÇADO TRINDADE, 2007, p. 208).
\end{abstract}

\title{
REFERENCES
}

AMARAL JÚNIOR, Alberto do. Direitos humanos e comércio internacional: reflexões sobre a "cláusula social". In AMARAL JÚNIOR, Alberto do, PERRONE-MOISÉS, Cláudia (orgs.). O cinqüentenário da Declaração Universal dos Direitos do Homem. São Paulo: Editora da Universidade de São Paulo, 1999, p. 197-216.

AMARAL JÚNIOR, Alberto do. Introdução ao Direito Internacional Público. São Paulo: Atlas, 2008.

AMARAL, Antonio Carlos Rodrigues do. O direito do comércio internacional na era da globalização: liberalização e integração econômica. In: AMARAL, Antonio Carlos Rodrigues do (Coord.). Direito do Comércio Internacional: aspectos fundamentais. São Paulo: Aduaneiras, 2004. p. 39-54.

BILCHITZ, David. The Ruggie Framework: An adequate rubric for corporate human rights obligations? SUR - International Journal on Human Rights. v. 7, n. 12, Jun. 2010, p.209-241. Available at: http://sur.conectas.org/wpcontent/uploads/2017/11/sur12-eng-david-bilchitz.pdf Accessed 03 Dec. 2018.

CALIARI, Aldo. Trade, Investment, Finance and Human Rights: Assessment and Strategy Paper. SUR - International Journal on Human Rights. v. 6, n. 11, Dec. 2009, p.141-159. Available at: http://www.scielo.br/pdf/sur/v6n11/en 08.pdf. Accessed 04 Dec. 2018. 
Belo Horizonte: Del Rey, 2006.

CANÇADO TRINDADE, Antônio Augusto. Desafios e conquistas do direito internacional dos direitos humanos no início do século XXI. In MEDEIROS, Antônio Paulo Cachapuz de. (org.) Desafios do direito internacional contemporâneo: Jornadas de Direito Internacional Público no Itamaraty. Brasília: Fundação Alexandre de Gusmão, 2007, p. 207-321.

CERNIC, Jernej Letnar. Corporate human rights obligations and international investment law. ACDI, Bogotá. Vol. 3 Especial, p. 243-273, 2010.

DI SENA JÚNIOR, Roberto. Comércio internacional \& Globalização: a cláusula social na OMC. 1 ed. 3 issue Curitiba: Juruá, 2006.

FARIA, José Eduardo. O futuro dos direitos humanos após a globalização econômica. In AMARAL JÚNIOR, Alberto do, PERRONE-MOISÉS, Cláudia (orgs.). O cinqüentenário da Declaração Universal dos Direitos do Homem. São Paulo: Editora da Universidade de São Paulo, 1999, p. 55-73.

FEENEY, Patricia. Business and Human Rights: The Struggle for Accountability in the UN and the future direction of the advocacy agenda. SUR - International Journal on Human Rights. v. 6, n. 11, Dec. 2009, p. 161-175. Available at: http://www.scielo.br/pdf/sur/v6n11/en 09.pdf. Accessed 04 Dec. 2018.

FORTES, Gabriel Barroso and POMPEU, Gina Marcilio. Os limites do Estado na promoção do desenvolvimento: democracia, direitos humanos e globalização. Direito e Desenvolvimento. João Pessoa, v. 7, n. 2, p. 57-76, 2017.

JUBILUT, Liliana Lyra. A proteção internacional do ser humano e as transformações no direito internacional. In VEÇOSO, Fabia Fernandes Carvalho (coord.). Direito Internacional em Contexto. São Paulo: Saraiva, 2012, p. 177-209.

LEADER, Sheldon. Interview with Sheldon Leader - Transnational Corporations and Human Rights by By Conectas Human Rigths. SUR - International Journal on Human Rights. v. 9, n. 17, Dec. 2012, p.107-113. Available at: http://www.scielo.br/pdf/sur/v6n11/en 08.pdf. Accessed 04 Dec. 2018.

MARQUES NETO, Floriano Peixoto de Azevedo. Regulação estatal e interesses públicos. São Paulo: Malheiros, 2002.

NUNES JUNIOR, Venilto Paulo. O conceito de soberania no século XXI. Revista de Direito Constitucional e Internacional. São Paulo, n. 42, a. 11, p. 144-166, Jan.Mar. 2003.

PERRONE-MOISÉS, Cláudia. Direitos humanos e desenvolvimento: a contribuição das Nações Unidas. In AMARAL JÚNIOR, Alberto do, PERRONE-MOISÉS, Cláudia (orgs.). O cinqüentenário da Declaração Universal dos Direitos do Homem. São Paulo: Editora da Universidade de São Paulo, 1999, p. 179-196. 
PIOVESAN, Flávia. Introdução ao sistema interamericano de proteção dos direitos humanos: a Convenção Americana de Direitos Humanos. GOMES, Luiz Flávio e PIOVESAN, Flávia (coords.). O sistema interamericano de proteção dos direitos humanos e o direito brasileiro. São Paulo: Revista dos Tribunais, 2000, p. 17-52.

RUGGIE, John Gerard. Just Business: Multinational corporations and human rights. New York, W.W. Norton \& Company, 2013.

SABA, Sérgio. Comércio Internacional e Política Externa Brasileira. Porto Alegre: Livraria do Advogado, 2002.

SILVEIRA, Vladimir Oliveira da; SANCHES, Samyra Haydêe Dal Farra Naspolini. Direitos Humanos, empresa e desenvolvimento sustentável. Direito e Desenvolvimento. João Pessoa, v. 6, n. 2, p. 145-156, Dec. 2015.

UNITED NATIONS - OFFICE OF THE HIGH COMMISSIONER FOR HUMAN RIGHTS. The corporate responsability to respect human rights. An Interpretive Guide. New York and Geneva, 2012. Available at: https://www.ohchr.org/Documents/Issues/Business/RtRInterpretativeGuide.pdf. Accessed 19 Oct. 2018.

UNITED NATIONS - OFFICE OF THE HIGH COMMISSIONER FOR HUMAN RIGHTS. Guiding Principles on Business and Human Rights. Available at: https://www.ohchr.org/Documents/Publications/GuidingPrinciplesBusinessHR EN.pd f. Accessed 19 Oct. 2018.

VASCONCELOS, Raphael Carvalho de. O direito internacional privado e a proteção do ser humano: a falácia da novidade. In RAMOS, André de Carvalho (org.) Direito Internacional Privado: Questões controvertidas. Belo Horizonte: Arraes Editores, 2016. 